\title{
An Investigation of Sexism in Egyptian Colloquial Arabic in Khaled Al-Khamissi's Taxi: A Feminist Stylistic Analysis
}

\section{Rania Abdel Meguid}

Assistant Professor, Faculty of Arts, Alexandria University, Egypt.

\begin{abstract}
Language is one of the most powerful tools of gender discrimination and maintaining sexism. The linguistic structures used by the speakers of a certain language reflect their view of the world as well as how they view themselves and others who belong to different social groups (e.g., women). This paper aims to investigate how Egyptian Colloquial Arabic (ECA), as used by a considerable number of Egyptian speakers, reflects discriminatory attitudes towards women. The paper presents an analysis of Khaled Al-Khamissi's Taxi which includes a collection of authentic dialogues between the author and a number of taxi drivers with whom he wandered through the streets of Cairo. The study adopts a Feminist Critical Discourse Analysis approach, using Sara Mill's (1995) model of feminist stylistic analysis, in order to reveal the sexism embedded in the Egyptian Colloquial Arabic expressions used mainly by the taxi drivers in the book through analyzing such expressions on the lexical, syntactic and discoursal levels. The study aims to shed light on how such expressions, used mostly without speakers being conscious of their sexist content, reflect a certain view of women among Egyptians.
\end{abstract}

Key words: Sexism, Feminist Critical Discourse Analysis, Egyptian Colloquial Arabic 


\section{Introduction}

Language is quite an honest and accurate reflection of reality. According to Litosseliti (2006, p. 13-14), "language is a powerful medium through which the world is both reflected and constructed". The linguistic structures used by the speakers of a certain language reflect their view of the world as well as their view of themselves and others who belong to different social groups. As Mills (2008, p. 18) puts it, language has a role to play in the construction of identity and is a resource which reflects how people think about their positions in society. As a result, "[t]oday's speakers inherit the idea that language is a weapon used by the powerful to oppress and silence their subordinates" (Cameron, 1992, p. 1). In other words, language use is essential to the establishment and maintenance of power relations between groups as language is a vehicle for stereotyping and discrimination (Hegarty, Korchmaros and Pratto, 2007, p. 221).

Among the groups whom linguists believe have always been deeply affected by the use of language are women. Menegatti and Rubini $(2017$, p. 1) argue that language is one of the most powerful tools which contribute to the perpetuation and reproduction of sexism and gender discrimination, and women are believed to have always suffered from a form of language that has come to be termed "sexist language". According to Cameron (1992, p. 100), feminists view sexism as discrimination against females rather than males, and hence, sexist language is language that discriminates against women "because it assumes women's subordinate position". Weatherall (2002, p. 10) argues that sexist language has attracted the attention of many feminist linguists who have advocated the use of non-sexist language, arguing that "words are not neutral but deeply ideological". This is because, according to Weatherall (2002, p. 11), sexist language "is not just about the words used to describe women but also how they are used and to what ends" (emphasis mine). As Mills (2008, p. 1) argues, "sexism, just like racism and other discriminatory forms of language, stems from larger societal forces, wider institutionalised inequalities of power and ultimately, therefore, conflict over who has rights to certain positions and resources". Accordingly, "the trouble provoked whenever feminist issues are raised about words and women is [...] an indication that issues of sexist language are inextricably tied to the prevailing social and moral order". In other words, "language about women is not a neutral or a trivial issue but deeply political" (Weatherall, 2002, p. 10). Hence, the language used in a certain community reveals the moral and political struggles over whose voice is to be represented and mediated (Mills, 2008, p. 9).

\section{Research Questions and Objectives}

Through analyzing a collection of utterances collected from Taxi by Egyptian author and journalist Khaled Al-Khamissi, this paper aims to investigate sexism in Egyptian Colloquial Arabic (ECA) as used by a considerable number of Egyptian speakers. Using the model of feminist stylistic analysis proposed by Mills (1995), this paper aims to answer two main questions:

1. How far does the lexical, syntactic and discoursal analysis of certain expressions used by many Egyptian speakers reveal sexism against women in ECA?

2. Should the language prove sexist, how does such sexism in language affect the view of women in the Egyptian society? 


\section{Review of the Literature}

\subsection{Sexist Language}

According to Wodak (1997, p.7), the term "sexism" was invented in the 1960s, on analogy to the term "racism", in order to refer to "discrimination within a social system on the basis of sexual membership". Litosseliti (2006, p. 13) argues that sexism takes place within a society where there is a hierarchical relationship between men and women and where one of the sexes (mostly men) is the norm and the other sex (mostly women) is marked as the "other" and is, therefore, treated as inferior. This happens "in relation to a wide range of social practices where women (and in some cases men) are exploited, manipulated or constrained because of their sex" (Litosseliti, 2006, p. 13). Although the term sexism is now used to refer to ideas and practices which treat either sex unfairly, it was originally coined "to refer to ideas and practices that downgrade women relative to men" (Cameron, 1992, p. 99).

In addition to sexist ideas and practices, sexism is also reflected in the language used by a certain community. The issue of sexism in language has drawn the interest of many linguists. According to Mills (2008, p. 1), the issue of sexist language which discriminates against women, belittles them and trivializes activities associated with them has been debated within feminist circles since the 1960s. This is because for feminist theorists and linguists (e.g., Robin Lakoff), sexism in language reflects sexism within society itself (Mills, 1995, p. 64). Those feminist theorists and activists were concerned with "trying to change the way women were represented in advertisements, newspapers and magazines, and also the way they were named and addressed in texts and interaction". As for the emergence of sexist language, Spender (1980, p. 143) argues that

it has been the dominant group - in this case, males - who have created the world, invented the categories, constructed sexism and its justification and developed a language trap which is in their interest $[\ldots]$ Males [...] have produced language, thought and reality. Historically it has been the structures, the categories and the meanings which have been invented by males $[\ldots]$ and they have then been validated by reference to other males. In this process, women have played little or no part.

However, several linguists have argued that language is not sexist in itself. In other words, it is basically the context in which a language is used that gives rise to a "sexist language". The structures representing males and females in a language "are characterized by asymmetries which communicate evaluations and stereotypes" as they are affected by the "gender belief system" prevalent in the speech community (Stahlberg, Braun, Irmen and Sczensny, 2007, p. 163). Hence, the context of power relations that hold between men and women in a patriarchal culture gives rise to expressions and utterances that are liable to sexist interpretations (Cameron, 2006, p. 16). The resulting sexist interpretations, in turn, contribute to constructing and maintaining the society's "belief system" (Stahlberg, Braun, Irmen and Sczensny, 2007, p. 163).

Lazar (2005, p. 1) argues that "the workings of gender ideology and asymmetrical power relations in discourse are assuming more subtle forms in the contemporary period", and Swim, Mallett and Stangor (2004, p. 117) argue that sexist language is a form of this "subtle sexism" as opposed to "blatant sexism" and "covert sexism". They explain that both blatant and covert sexism are intended forms of sexism which result in an unequal and unfair treatment of women. Blatant sexism is purposefully hidden, whereas covert sexism is not. Subtle sexism, on the other hand, "represents unequal and unfair treatment of women that is not recognized by many people because 
it is perceived to be normative, and therefore does not appear unusual" (Swim, Mallett and Stangor, 2004, p. 117). With regard to sexist language, Hyde (as cited in Swim, Mallett and Stangor, 2004, p. 117) argues that it is learned at an early age and can be considered a "linguistic habit". In other words, "we become habituated to certain ways of talking, writing and interpreting which we then adopt and use more or less unthinkingly" (Mills, 2008, p. 9). As a result, one reason why people may be using sexist language is that they do not really realize that it is sexist as it has become traditional and difficult to change. Cameron (1992, p. 6) explains that feminist analyses are generally based on the notion of "conditioning"; this means that "if you are exposed repeatedly to stereotypes and distortions, you will come to believe them and take them for granted" As a result, sexist language contributes to representing women in a less favourable light, and many speakers use it without meaning to discriminate against women or even realizing how this kind of language has discriminatory results (Menegatti and Rubini, 2017, p. 1). Another reason why people may be using sexist language is that since sexist language is reflecting of the gender beliefs and the asymmetries between men and women, it is used in order to protect established social hierarchies (Swim, Mallett and Stangor, 2004, p. 117). Eventually, sexism, with sexist language being one of its manifestations, forces language users to accept the status quo and the belief that women are indeed inferior to men. As a result, women cannot intervene in the process whereby they are oppressed and cannot change their status in society (Mills, 1997, p. 44). Sexism, perceived as a kind of oppression, led to the rise of feminist movements aiming to combat it.

\subsection{Feminist Attempts to Combat Sexism}

The term "feminism" does not have one meaning on which all scholars agree. In other words, there are many "feminisms" which are informed more or less by the same beliefs (Cameron, 1992, p. 4). According to Bucholtz (2014, p. 23), feminism is "a diverse and sometimes conflicting set of theoretical, methodological, and political perspectives that have in common a commitment to understanding and challenging social inequality related to gender and sexuality". Despite the vigorous differences between the different versions of feminism, "they share a commitment to addressing social inequality" (Bucholtz, 2014, p. 23). However, the feminist movement aims for "the full humanity of women" rather than "the rights" of women or the "equality" between men and women because "[e]quality presupposes a standard to which one is equal: in this case, the implied standard is man" (Cameron, 1992, p. 4). Cameron adds that the ultimate goal of feminism is to understand how the relations between men and women are constructed and how they could be changed in the light of this understanding (1992, p. 4).

Research on gender and sex in sociolinguistics and discourse analysis goes back to the 1970s (Wodak, 1997, p. 1). Research on gender and language has always been divided into two main fields: the representation of gender in the language and how both men and women use language in terms of phonological behaviour and conversation style (Wodak, 1997, p.1; Speer, 2005 , p. 3). Studies tackling how both genders are represented in the language are based on the belief that language is "an ideological filter of the world" and that language, hence, "reflects and perpetuates a sexist and heterosexual version of reality" (Speer, 2005, p. 3). Interest in the relationship between gender and language led to the emergence of feminist linguistics.

Feminist linguistics "is interested in identifying, demystifying, and resisting the ways in which language is used, together with other social practices, to reflect, create and sustain gender divisions and inequalities" (Litosseliti, 2006, p. 23). Although feminist linguistics developed within linguistics rather than feminism, this development can be placed in context with reference 
to the three waves of feminism. Pre-modernist or "first-wave" feminism could be linked to the suffragette movement which emerged in the 19th and 20th centuries. Modernist or "second-wave feminism" emerged in the 1960s and could be associated with resistance against sex discrimination as well as the promotion of equal opportunities and the emancipation of women. Finally, "thirdwave" feminism "is concerned with the diversity, multiplicity, performativity, and co-construction of gender identities within specific contexts and communities of practice, and on the politics of power construction and subject positions" (Litosseliti, 2006, p. 23). Mills (2002) argues that feminist linguistics shares the assumptions and principles of third-wave feminism.

Cameron (1992, p. 6) argues that one of the main objectives of the many writings about feminism and linguistics was to "question the whole scholarly objective bias of linguistics and to show how assumptions and practices of linguistics are implicated in a patriarchal ideology and oppression". This is because, according to feminist linguists, the meaning of words is not fixed but fluid. A word is sexist or egalitarian depending on its use within a certain social community, and that is why feminist linguists view meanings of linguistic items as "socially constructed" (Speer, 2005 , p. 4). In other words, "we can avoid or affirm certain views of women and men by drawing on certain discursive resources" (Mills, 1998, p. 8). Hence, the need for a feminist linguistic analysis emerged in order to examine what kind of language would be considered sexist in a certain language community, how this sexist language affects women and how this language can be combated for the benefit of women.

\subsection{Sexism in Egyptian Arabic}

Not much scholarly attention has been paid to investigating sexism in ECA, and the few studies that have been published on this issue tend to focus on one aspect of sexism in the language. For example, Farwaneh (2005) examines examples of sexism in various varieties of the Arabic language, including Modern Standard Arabic (which is mostly used in writing) in addition to a number of spoken varieties. Her study is mainly concerned with sexism exhibited on the word level like cases of avoidance (the absence of a morphologically possible gender-related term, e.g., 'āhirah, meaning "whore", does not have a male counterpart), semantic shift/derogation (when both gender forms exist but do not exhibit similar connotations, e.g., waliyy, meaning "a holy man" vs. the feminine form wiliyyah, which is a derogatory form for "woman") and incongruence (when the morphological gender of a word is not the same as the sex of the referent, e.g., the word tâliq, meaning "divorced", is used in the masculine form even though it refers to women). In another study, Nayef and El-Nashar (2014) investigate gender stereotyping through analyzing sexist Egyptian Internet jokes. They conclude that such jokes reflect bias against women through manipulating language to maintain gender inequality, associating women with the private sphere and men with the public sphere, representing women as sex objects and comparing Egyptian women to non-Egyptian women. Hence, to the best of the researcher's knowledge, sexism in ECA has not yet been investigated on all the lexical, syntactic and discoursal levels, which is the gap that this paper attempts to fill.

\section{Methodology}

This paper adopts a Feminist Critical Discourse Analysis (FCDA) approach to analyze the sexism embedded in the use of ECA as used in a number of conversations with taxi drivers in the Egyptian capital Cairo. These conversations are recorded in a book entitled Taxi by Khaled AlKhamissi, an Egyptian author and journalist. The analysis aims to investigate the sexist use of ECA and how it contributes to disadvantaging women as a social group in the Egyptian society. 
The model of analysis which is used to analyze the data is the one proposed by Mills (1995), which comprises a number of linguistic tools derived from different theories, in order to analyze sexism in language.

\subsection{Feminist Critical Discourse Analysis}

According to Fairclough (1989, p. 22), discourse is "language as a form of social practice". Sunderland (2004, p.11) states that discourse is socially conditioned because it is shaped by material and social structures. In addition, it is socially constitutive because it is "not only a form of knowledge about cultural ways of thinking and doing, but also, more powerfully, a potential and arguably actual agent of social construction" (Litosseliti and Sunderland, 2002, p. 13). This means that discourse has a visible effect on social reality.

Discourse has effects on social reality through the ideologies it encloses. Through spreading such ideologies and making them common sense, discourse gives power to a certain social group over another. The field which is concerned with revealing the relation between discourse, power and ideology is Critical Discourse Analysis (CDA). Van Dijk (2001, p. 352) defines CDA as "a type of discourse analytical research that primarily studies the way social power abuse, dominance and inequality are enacted, reproduced, and resisted by text and talk in the social and political context". According to Lazar (2005, p. 2), CDA is best known for its political stance and is characterized by its concern with challenging all forms of social inequality and injustice. Lazar (2017, p. 372) states that CDA seeks to "raise critical consciousness about the discursive dimensions of social problems involving discrimination, disadvantage, and dominance". She argues that the ultimate goal of CDA is contributing to "broader emancipatory projects".

Since sexism and the use of sexist language are both forms of social inequality and injustice, Lazar (2005, p. 3) explains that it was necessary within CDA to establish "a distinctly feminist politics of articulation". In other words, there was a need for theorizing and analyzing from a critical feminist perspective "the particularly insidious and oppressive nature of gender as an omni-relevant category in most social practices". Mills (1998, p. 235) argues that one of the main reasons why a new form of feminist analysis is needed is that feminism has had an impact on sexism and how gender relations are discussed in the public sphere. Thanks to feminist theory, sexism has undergone much change for it has become more indirect or subtle, and more direct or overt sexism has been driven underground and has even become less common in texts (Mills, 1998, p. 237). This led to the emergence of feminist CDA (FCDA) which is a branch of CDA that is concerned with studying and analyzing the relations between gender, discourse and ideology.

According to Lazar (2005, p. 5), the main concern of FCDA is "critiquing discourses which sustain a patriarchal social order: that is, relations of power that systematically privilege men as a social group and disadvantage, exclude and disempower women as a social group". In other words, as Lazar (2017) argues, FCDA investigates how gender ideologies become "common sense" via being entrenched in discourse contexts in certain communities (p. 372). FCDA considers "gender" as an ideological structure and practice which creates binary oppositions between men and women via hierarchically dividing people into two blocs based on their natural sex. Hence, the objective of FCDA is to demystify and challenge discourses which continue in various ways to harm one social group (women) for the benefit of another (men) (p. 372). This is through drawing attention to and changing the way gender is represented in discourse (Mills, 1995, p. 1). 


\subsection{Mills' Model of Feminist Analysis (1995)}

Mills (1995) presents a model of analyzing gender bias in language. Her model comprises three levels of analysis that aim to reveal sexism in language. These are:

1. The lexical level

On the lexical level of analysis, there are a number of categories which can be used to analyze sexism in language. These include naming and androcentrism, the semantic derogation of women, endearments and diminutives, female experience (especially euphemism and taboo), lexical gaps (male point of view), and collocation.

2. The syntactic level

The syntactic level of analysis in Mills' model is concerned with examining sexism in language via analyzing ready-made phrases, jokes and humour (which will be analyzed in this paper using Attardo's General Theory of Verbal Humour), metaphor and transitivity choices (which will be analyzed in this paper using Halliday's theory of Systemic Functional Grammar).

3. The discoursal level

The discoursal level of analysis in Mills' model is concerned with examining sexism in language via analyzing the description of characters, the roles female characters can fill in a text, fragmentation, focalization and schemata (which will be analyzed using the schema theory proposed by Brown and Yule).

The analysis of the data will tackle the categories which feature in the conversations in Khaled Al-Khamissi's Taxi. Although an English translation of the book by Jonathan Wright is already available, the researcher has opted for translating the examples herself due to some reservations against the published English translation; some instances of Wright's translation, especially items that are very culture specific, are not very accurate, and hence, the translation would better be provided by a person who is familiar with the Egyptian culture.

\section{Description of the Data}

The data analyzed in this paper is a book entitled Taxi by Khaled Al-Khamissi, an Egyptian author and journalist. The book comprises 58 short stories, in each of which the author narrates an authentic dialogue (which he tries, as much as possible, to record faithfully as he mentions in the introduction) with an Egyptian taxi driver while they are roaming together the streets of the Egyptian capital Cairo. In the introduction of the book, the author mentions that he has always been interested in having conversations with taxi drivers whom he regards as one of the "thermometers" of the Egyptian population. This is because, he argues, they have deep knowledge of the Egyptian society as they "practically live on the streets and meet a huge number of different people on a daily basis".

In linguistic terms, the book has been chosen for analysis for a number of reasons. First, although the narrative parts of the book are written in Modern Standard Arabic (MSA), the dialogues with the taxi drivers have been "copied" as they are, that is, in Egyptian Colloquial Arabic (ECA). ECA is the variety of Arabic which Egyptians use for speaking mainly in Cairo and Alexandria as there are other dialects used in other Egyptian governorates. Second, the drivers with whom the author had dialogues, which are representative of this group of people in general, 
belong to various social classes, "from illiterate drivers to drivers who are MA holders" as mentioned in the introduction of the book. Accordingly, the kind of language used in the book is a language used by several social classes in Egypt. The third reason, and based on the first and the second reasons, is that analyzing how women are represented in ECA, which is used by a large population in Egypt, would be telling of how women are generally viewed in the Egyptian society. Should the language prove sexist, this would be reflecting of a larger-scale discrimination against women in the Egyptian society.

\section{Data Analysis}

\subsection{Lexical Analysis}

\subsubsection{Naming}

Mills (2003, p. 88) argues that naming is of paramount importance, for names are essential for the construction of reality; it would be difficult to accept the existence of objects, events and feelings if they do not have names. According to Mills (1995, p. 78), naming is one means of maintaining sexism in a language. Cameron (1998, p. 9) notes that languages in general are sexist as "they represent or "name" the world from a masculine viewpoint and in accordance with stereotypical beliefs about the sexes". Such names are mere reflections of reality in which the language used is "man-made" as described by Spender (Mills, 1995, p. 78).

There are naming strategies in ECA that seem to reflect sexism against women. For example, Mills (1995, p. 78) argues that a language can be considered sexist if women's sexuality influences its linguistic resources. In ECA, women's sexuality is a source of many swearing words. For example, in the data analyzed, the expression wiläd al- 'ahbah (sons of bitches" is used repeatedly by drivers. The word 'ahbah originally comes from MSA and means "a prostitute" ( $A l$ mu '̌gam al-wă̌iz, 2005), but now it has become a taboo ECA word. According to Hughes (2015, p. 364), "[t]erms for prostitutes form perhaps the most powerful and extensive word-field for abuse and swearing in the language". In story (2), the expression wiläd al- 'ahbah is used by the driver twice; he uses it once in the singular form 'ibn 'ahbah (son of a bitch) to describe a police secretary who forcefully took money from him, threatening to withdraw his driving license if he does not give him money, and then he uses it again in the plural form to refer to all police secretaries when he describes them as "all bribe-takers and thieves". In story (56), it is used in the singular form by the driver to describe a university professor who is being unkind to his brother who works as a demonstrator in the Sociology Department at the Faculty of Arts, and the driver claims that the professor is being unkind to his brother simply because the latter is a Christian. In both situations, the drivers decide to use a swearing word which is related to women's sexuality to describe their opponents. The same applies to the taboo word šarmuttah (whore) used in story (31) by a heartbroken driver who tells the author/narrator that the worst thing in the world is inn hadd yihibb la $m o$ 'ähza šarmüțah (to fall in love with, excuse my language, a whore). He goes on with his story about the woman he fell in love with before discovering that she is a "whore" (the word šarmütah being used in this context both as a description of the woman's sexual behaviour and as an insult). Using swearing words which are derived from women's sexuality is revealing of how women are viewed as well as how society condemns women (though not necessarily men) who tend to engage in multiple sexual relations; the behaviour of such women becomes a source of swearing words used against people whose behaviour is deemed immoral. 
There are other ECA examples in which women's sexuality is a source of cursing words. In story (12), the author tries to convince the driver to be a fan of Al-Ahly Football Club when the driver is a fan of Al-Zamalek Club, both clubs being the biggest, most popular and most prestigious football clubs in Egypt. The driver refuses to abandon Al-Zamalek club (which is known to have been repeatedly defeated by Al-Ahly), arguing that "al-zamālik hâltoh miḍ 'da' a wā 'ammāl yikaskis liwarah miš zayy al- 'ahli fì al- 'alālì miš miḥtāg wala wāḥid yišagg 'oh" (Al-Zamalek is weak and keeps deteriorating, unlike Al-Ahli which is already on top and does not need more fans). The word yikaskis (to deteriorate) is a taboo word in ECA and is believed to be derived from the word kuss (cunt) which Rosenbaum (2019, p. 165) describes as "the mother of obscene words". Hence, the word yikaskis is an example in which women's sexuality is used as a source of swearing words and words with negative connotations (in this context weakness). Such usages indicate how women's sexuality is negatively viewed by the speakers of ECA.

Mills (1995, p. 80) argues that one more "stark reminder of the way in which naming informs the lives of women is when we consider the fact that there are differential codes for naming men and women themselves". In English, the marital status of women is revealed through terms of address like "Miss" and "Mrs.", whereas no terms of address are revealing of a man's marital status. In ECA, there is a similar case. For example, in story (57), a female employee working at a traffic administration office is referred to as madām (Mrs.). This contrasts with the word 'ustāz (sir) which is used repeatedly throughout the book to address the author/narrator. The word 'ustāz, unlike the word madam, does not reveal a man's marital status, which indicates how users of ECA tend to define women narrowly in terms of their relationship to another man.

\subsubsection{The semantic Derogation of Women}

Mills (1995, p. 83) argues that a language is sexist when gender-specific terms in this language "have a strong tendency to be derogatory towards women". Farwaneh (2005, p. 44) notes that such derogation occurs in cases "where both gender forms exist but exhibit inequitable semantic connotations, usually with semantic derogation of the feminine". Farwaneh $(2005$, p. 56) gives several examples from spoken Arabic which indicate how both the male and female terms begin on an "equal footing" before the feminine term degenerates over time. The word wiliyyah, an ECA derogatory term for "woman", used by the driver in story (2), is a case in point. According to Farwaneh (2005, pp. 56 - 57), the word waliyyah, which has been rendered wiliyyah by vowel raising, is originally the feminine form of the word waliyy, meaning "a holy man". However, with the passage of time, the feminine form has acquired a derogatory meaning, and the word wiliyyah has become a pejorative term meaning "woman". The word wiliyyah, hence, shows discriminatory attitudes towards women unlike its male counterpart waliyy which shows respect, and this reflects a kind of sexism towards women embedded in ECA.

The type of gender-specific terms available to language users to describe males and females in relation to sexual activity is another indicator that helps identify sexism in a language (Mills, 1995 , p. 86). The word 'ahbah used in stories (2) and (56) is a derogatory term and one of the worst taboo words in ECA. In addition to meaning "whore", it is also used as an insult. In ECA, the terms used to refer to a man who is involved in many sexual relations, on the other hand, have an element of boastfulness and are used as a kind of praise like mi'ațta 'al-samakah wā deelhā. Such expressions are reflecting of how male and female sexuality are viewed in the Egyptian society; a male with multiple sexual relations is tolerated, whereas a female's sexuality should be monitored as it is considered an issue of social concern, and females breaking the rules pay a costly 
price for that and get stigmatized. On another note, the word 'ahbah exhibits a case of "avoidance". The term "avoidance" refers to "the absence of one gender category in a pair, rendering gender patterns incongruent" (Farwaneh, 2005, p. 44). Farwaneh mentions the English words "virgin" and "whore" as examples of terms "with exclusively feminine reference" and which have no male counterparts (ibid, p. 44). Farwaneh (2005, p. 44) argues that

[v]irginity and whoredom, which occupy the opposite poles of the sexual experience continuum, are culturally perceived as female-exclusive. Female virginity is a primary prerequisite for marriage, while male virginity is neither required nor desired. Sexual promiscuity, on the other hand, is observed, documented and penalized only if the agent is a female, hence the need to coin a feminine referential term for 'whore'; promiscuity among males goes unnoticed, and if noticed, escapes sanction; hence, the absence of masculine counterpart.

The word 'ahbah in ECA, like the words "whore" and "virgin" in English, has no male counterpart. The same applies, to an extent, to the word šarmütah; even the male form šarmüt seems to be derived from the feminine form via clipping the feminine marker and is merely used as an insult without having to do with a man's sexual behaviour. Moreover, Rosenbaum $(2019$, p. 166) argues that the word šarmūt is used to describe a man "who does not behave as a man and therefore is depicted as a woman of the cheapest kind". In the light of Farwaneh's argument, this is because of the extreme importance society attributes to women's sexuality and how it is socially linked to morality. As Stahlberg, Braun, Irmen and Sczensny (2007, p. 168) put it, the lack of male counterparts of words like "virgin" and "whore" constitutes a "lexical gap" that correlates with the gender belief system and traditions in a speech community; this is because society attaches much importance to female, and not male, chastity. As a result, "more words are available to insult women, especially in sexual terms, and [...] words for women's bodies are more taboo than those for men's" (Cameron, 1992, p. 107). The same applies to the ECA words 'aḥbah and šarmütah.

\subsection{Syntactic Analysis}

\subsubsection{Presupposition and Inference}

Based on Brown and Yule, Mills (1995, p. 100) argues that in understanding an utterance, the receiver of a linguistic message needs to follow three steps. First, he/she needs to try to understand the intention of the speaker/writer. Second, he/she needs to use his/her linguistic knowledge as well as world knowledge to decode the linguistic message. Third, he/she needs to determine the inferences which need to be made. Some of the inferences language receivers (readers or listeners) are able to draw are based on presuppositions.

According to Richardson (2007, p. 63), a presupposition is "a taken-for-granted, implicit claim embedded within the explicit meaning of a text or utterance". Richardson argues that presuppositions can be triggered by a number of linguistic items like change of state verbs (e.g., "stop", "begin"), implicative verbs (e.g., "manage", "forget"), the definite article "the", possessive articles, wh- questions and nouns and adjectives used to qualify noun phrases (pp. 63-64). According to Mills (1995, p. 102), "phrases working on the basis of assumed knowledge [...] can have a strong ideological impact in persuading people that they are in fact an accurate version of reality". In story (9), the driver, criticizing hijabi girls, says "šüf al-banțaloon al-mihazza" wā alhibāb 'illi milattahīn bïh hil'ithom" (look at their tight trousers and the muck they smear on their faces). The presupposition, which is triggered by the definite article al-, here is that those hijabi 
girls do wear tight clothes and put on makeup, even though this is regarded as inappropriate for hijabis. The message carries the driver's ideology, implying that those girls are the reason for the moral deterioration in the Egyptian society. The driver adds, "sa 'attak al- 'arab beyigo wä biyimlo al-mohandisìn, tiboss hadritak tilā'i al-banāt fì gām it al-diwal al- 'arabiyya wā al-bațal 'aḥmad 'abdil 'azizz zayy al-naml" (The Arabs come, sir, and fill the Mohandeseen district. If you look around, you will find the Arab League Street and Ahmed Abdel Aziz Street full of girls). This utterance serves to convey the same message. The hearer is likely to draw an inference that those girls, who fill these streets, get involved in relationships with those rich Arabs, especially that these areas in Cairo have this reputation. According to Short (2013, p. 222), "to infer appropriate meaning from what is said or written often crucially depends upon applying relevant assumptions about the world $[\ldots]$ to the linguistic message". This contributes to the driver's message that girls, being immoral, are responsible for destroying the Egyptian society and enforces a negative image of women. Similarly, in story (11), the driver starts his story by saying, "wahdah munaqqabah rakabit ma 'âya" (a woman in face veil got on the taxi). He then goes on with the narrative to tell how this woman starts to take off her clothes on the car. The inference to be drawn from describing the woman as wearing face veil tells something about the driver's ideology; if this is her appearance, she is likely to be respectable since covering a woman's body is a criterion against which a woman's morals are judged in the Egyptian society. That is why her taking off her clothes comes as a shock to the man; it contradicts his expectations about her morals. Such examples show how certain inferences are to be drawn about women's morals in the Egyptian society from their clothing. Covering up is directly connected to a woman's morals.

\subsubsection{Jokes and Humour}

Mills (1995) argues that sexism sometimes comes disguised under the cover of humour (p. 106). This makes matters difficult for women who may complain about the content of such jokes as the expected reply would usually be something like "It's just a joke" or "I was just joking" (p. 107). As a result, language users who tell sexist jokes contribute to perpetuating the sexism embedded in these jokes (p. 106).

Raskin (1985, p. 99) argues that a text can be characterized as such if, and only if, the text is compatible with two different scripts and if these two scripts are said to overlap fully or in part in this text. According to Attardo's (2001) General Theory of Verbal Humour (GTVH), a joke consists of six Knowledge Resources: the script opposition (SO), the logical mechanism (LM), the target (TA), the narrative strategy (NS), the language (LA) and the situation (SI) (pp. 20-25). The language refers to the information necessary for the verbalization of a joke. The narrative strategy refers to the narrative organization of a joke (simple narrative, dialogue, etc.). The target is the butt of the joke. The situation refers to the "props of a joke (objects, participants, instruments, etc.). The logical mechanism presupposes a local logic that does not necessarily hold outside the world of a joke. The script opposition refers to the opposition between real and unreal situations in the text. Attardo proposes that a joke has the following structure:

Joke: $\{$ LA, SI, NS, TA, SO, LM $\}$ (Attardo, 2001, p. 27)

In story (50) in the data analyzed, the author relates a number of jokes that taxi drivers share while they are waiting to fill up their cars at the gas station. The jokes can be broadly divided into two types: political jokes and sexual jokes (which way outnumber the political ones). Examples of these jokes include: 
a) bi monāsbit 'aṭnān al-viyāgrah 'illī 'afašūha fì al-mīnah fì šohnnit al-siramīk hatisma o al'i 'lān da bukrah fì al-rādyoh: sirāmīk bì al-viyāgrah 'ašān al-sittāt tihalī al-riggālah tilhas albalāt (They found tons of Viagra at the port in a consignment of ceramics. You will hear this advert on the radio tomorrow: "Ceramics with Viagra, so that women can make their men lick the tiles.")

b) sawwā' tāksī zihi' min mirātoh katab 'i 'lān 'àl fìh li al-badal zawgah bi hạlah gayyidah, dawāhil fabrīkah, sidr kahrabah, wirāk tyūblis, 'āmlah 'ashar talāf (A taxi driver was fed up with his wife, so he put an ad saying: "For exchange, one wife in good condition, factory-made interior, electric fenders, tubeless thighs, only 10000 pounds)

c) ma'ādīr 'istihdām al-viyāgrah: ma 'bitt 'awwil marrah tišufha miš miḥtāg, ma 'habibtak noss habbāyah, ma' 'ašì'tak habbāyah, ma' mirātak sitt habbayāt wā 'ašarah bīrah wā talātah wiskī wā sigārteen haš̌̀̌s wā șārūh bāngo wā rabbina yisahhil yā yinfa' yā māyinfa '̌s (Dosage for using Viagra: With a girl you're meeting for the first time, no need. With the woman you love, half a pill. With your girlfriend, one pill. With your wife, six pills, 10 beers, three whiskeys, two joints of hashish, and one of grass and God help you. It may work or it may not.)

To start with, all three jokes have women as their target (TA). Mills (1995, p. 107) argues that sexist humour is generally seen as "a male domain" where "women are usually seen as the butt of jokes rather than as active agents in their construction". The narrative strategy (NS) used in joke (a) is a simple narrative, and the situation (SI) is finding Viagra in a consignment of ceramics. The joke draws a parallelism between an invented advertisement about "Viagra Ceramics" and a famous Egyptian ceramics advertisement about "Cleopatra ceramics", both titles rhyming in terms of language (LA). The schema opposition arises from the opposition between the actual use of ceramics (i.e., tiling bathrooms) and the role of ceramics in the joke (i.e., forcing men to make love to their wives as a result of containing Viagra), which produces the comic effect of the joke. The logical mechanism (LM) of the joke could be viewed as depicting women as sexual objects who are pursed by men only for sex. Hence, in a way, it reflects how women in the Egyptian society are viewed by men. Similarly, joke (b) has the narrative strategy (NS) of a simple narrative, and the situation (SI) is that a man is putting his wife on sale because he is fed up with her. The language used (LA) presents a kind of analogy between a wife and a car, comparing a woman's body parts to parts of a car, both presenting two different scripts. The logical mechanism (LM) of putting the wife on sale is that the wife is an object owned by the husband, just like his car. Hence, the joke objectifies women, presenting them as objects that men can dispense with just like cars, which is sexist. The narrative strategy (NS) of joke (c) is a statement, and the situation (SI) is the using different doses of Viagra for having sex with different women. The script opposition can be seen as follows: Viagra helps a man in having sex with his wife (expectation) vs. Viagra can never be enough if a man is trying to have sex with his wife (reality in the world of the joke). The language (LA) of the joke presents a comparison between having sex with various women (which is easy) as opposed to having sex with a man's wife (which nothing can help with). The logical mechanism (LM) is that wives are insufficient to satisfy their husbands' sexual desires to the extent that a man needs to resort to drugs that may or may not help him in his sexual relation with his wife. Such sexist jokes, in addition to serving as "a form of bonding and solidarity display" (Mills, 1995, p. 107), serve to perpetuate stereotypes about women (e.g., as sex objects, as objects possessed by men, as insufficient to satisfy their husbands' sexual desires). They are created by men, and they indicate how women are viewed by men in the Egyptian society. 


\subsubsection{Transitivity Choices}

Halliday proposes that language has three basic metafunctions: the ideational function, the interpersonal function and the textual function. The ideational function expresses that "the experiential and the logical content of the text explains our experience of the outer world in the environment;" the interpersonal metafunction "deals with the social and power relations among language users" and "relates participant's situational roles to the discourse produced;" the textual function is "language-oriented and deals with cohesive and coherent text production by organizing and structuring the linguistic information in the clause" Haratyan (2011, p. 261). Wales (2011, p. 426), argues that "[ $\mathrm{t}]$ he different patterns of transitivity are the prime means of expressing our internal and external experiences, which is part of the ideational function of language". The transitivity system construes the world of experience into a set of "process types". Our experience of a particular event can be represented in a variety of ways (Simpson, 1993, p. 87), and transitivity refers to how this experience is represented in the clause. Transitivity "shows how speakers encode in language their mental picture of reality and how they account for their experience of the world around them" (Simpson, 1993, p. 88).

The way in which transitivity carries out this experience is by expressing processes. Halliday states that a process consists of three components:

1- the process itself (expressed by the verb phrase in a clause);

2- the participants involved in the process (realized by noun phrases in the clause);

3- the circumstances associated with the process (expressed by adverbials and prepositional phrases).

Halliday (1994, p. 107) divides processes into three main categories: material processes, mental processes and relational processes. Material and mental processes are processes of the external world, that is, what we experience as going on out there in the world around us. Relational processes, on the other hand, have to do with inner experience as they help us relate one fragment of experience to another. A material process is a process of doing, and the participants of a material process are an Actor (performer of the action) and a Goal (the party an action is performed on) (Halliday, 1994, p. 109). A mental process is a process of sensing (Halliday, 1994, p. 112); its two main participants are a Senser, which is "the conscious being that is feeling, thinking or seeing" (Halliday, 1994, p. 117), and a Phenomenon, which is "sensed" (Halliday, 1994, p. 117). A relational process is a process of being (Halliday, 1994, p. 119). The participants of a relational process are the Carrier, which is roughly the "topic" of the clause, and the Attribute, which is a description of or a comment on the topic of the clause.

In addition to these three main categories of processes, Halliday adds three subcategories: behavioural processes (on the borderline between material and mental processes), verbal processes (on the borderline between mental and relational processes) and existential processes (on the borderline between relational and material processes). Behavioural processes are processes of "physiological and psychological behaviour, like breathing, coughing, smiling, dreaming and staring" (Halliday, 1994, p. 139). Verbal processes are processes of saying which have the Sayer (the one who says), the Receiver (the one to whom the saying is directed), the Verbiage (what is said) and the Target (the entity targeted by the process of saying) as their participants (Halliday, 1994, p. 140). Existential processes are processes which indicate that 
something exists or happens (Halliday, 1994, p. 140). In the data analyzed, various process types are assigned by the taxi drivers in their speech to the women mentioned in their stories.

Although the use of a highly material paradigm "creates a highly "actional" descriptive framework" (Simpson, 1993, p. 97), the material processes assigned to women in the conversations do not show them as being in control. Rather, they contribute to the creation of an image of them as having certain characteristics. For example, many material processes assigned to women have to do with taking care of their looks. Examples include:

a) al-bint tilbis fanillah wā banțaloon wā ka'annahā lā talbis shee' (girls wear T-shirts and trousers, but they look as though they were wearing nothing) $\rightarrow$ story (9)

b) haḍitak māyhilš 'aleek al-higāb 'illi homma lāasīnoh" (Sir, do not be deceived by the veil they are wearing) $\rightarrow$ story (9)

c) šüf al-banțaloon al-mihazza' wā al-hibāb 'illi milattahīn bīh hil 'ithom" (look at their tight trousers and the muck they smear on their faces) $\rightarrow$ story (9)

d) badit tihott 'ahmar šafāyif (she started to put on lipstick) $\rightarrow$ story (11)

e) lābsah jībah 'oṣayyarah wā lābsa šarāb 'iswid tih̆inn (wearing a short skirt and thick black socks) $\rightarrow$ story (11)

The material processes used in the above-mentioned examples all have to do with women (the Actors of the material processes) taking care of their looks. However, such processes show women in a negative light. In story (9), the driver criticizes women and girls who wear tight clothes and put on makeup, arguing that they are the reason behind the moral deterioration that has plagued the Egyptian society as they seduce men. In story (11), the driver relates the story of a woman with a face-veil who takes off her veil in the taxi and starts wearing revealing clothes on the way. Having clothes and makeup as the Goal of the material processes assigned to women portrays women negatively as being more concerned with their looks than necessary and reflects how women in Egypt come under scrutiny, and may be severely criticized, for what they wear.

In addition, a number of material processes assigned to women contribute to portraying them as passive housewives who depend on men for protection and financial support. Examples include:

a) al-hukūma zara'it fina al-ro'b min al-gū' hallit koll zoogah timsik fì 'ìd gozha wā ti'olloh 'iw'à tinzil, al- 'iyāl hatmūt (The government instilled in us the fear of hunger. It made every wife hold her husband's hand and beg him saying, "Please do not go out; the kids will die.") $\rightarrow$ story (3)

b) 'ommohom monaqqabah wā mabtohrogš min al-beet (Their mother is face-veiled and does not leave the house.) $\rightarrow$ story (16)

In example (a), the verb timsik (hold) indicates a material process which signifies fear and seeking the husband's protection. It reflects the wife's fear of losing her husband as she thinks that if he is gone, this would be the end of the family. In example (b), the material process assigned to the mother is a negative one. She does not leave the house, and therefore, she is facing a grave problem as her husband is in prison and she cannot afford paying for the taxi driver to take her kids to school. Both material processes, in which women are Actors, indicate how passive and 
weak women are perceived to be, which means, by contrast, that men in the Egyptian society are perceived as strong and protective as opposed to women. Therefore, such material processes contribute to creating an image of women in the Egyptian society as generally weak and in constant need of men.

Women are also assigned a number of verbal processes in the data analyzed. In addition to the verb "say", which is assigned to women several times while reporting conversations they were engaged in with the taxi drivers, the verbal processes assigned to women are significant as they are telling of how they are viewed by men in the Egyptian society. Examples include:

a) mirātì dabbit ma 'āyah hinā'ah lil samah (My wife quarreled with me and the quarrel turned into a big fight.) $\rightarrow$ story (16)

b) wā hilfit 'inn 'ana miš ha'arrab minha geer lamma nisīb al-harrārah al-maskoonah 'illi 'ayšin fihā (And she swore she wouldn't allow me to sleep with her before we move from this haunted shithole to another house.) $\rightarrow$ story (44)

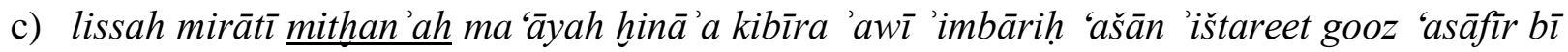
miteen wa hamsin gineeh (My wife quarreled with me yesterday, and the quarrel turned into a big fight, because I had bought two sparrows for 250 pounds.) $\rightarrow$ story (58)

In the above-mentioned examples, women are the Sayers of a number of verbal processes which contribute to creating a negative image of Egyptian women (i.e., women who keep quarreling and starting fights with men). In examples (a) and (c), derivatives of the ECA verb yithāni' (to quarrel) are assigned to women (the Sayers) with the Receivers of the quarrels being their husbands. In example (a), the wife quarrels with her husband for accepting to take kids to school for free as their mother cannot afford paying for the taxi. In example (c), the wife quarrels with her husband for spending a fortune on sparrows. In example (b), the wife is assigned the verbal process "swear" which, in addition to the Verbiage she uses (i.e., refusing to let her husband sleep with her unless they leave the house which she believes to be haunted) portrays her as obstinate and cruel. In each of the three examples, there seems to be a reason behind the wife's behaviour, and yet, the reason is backgrounded, and what is foregrounded is the wife's starting a fight. In examples (a) and (c), the reason for the quarrel is ignored (i.e., that the house needs the money), and the focus is on the verb "to quarrel", which portrays Egyptian women as fight initiators as opposed to men who are the victims of these fights. In example (b), the speaker focuses on his wife's negligence of his desires and consolidates this view through using the verbal process "to swear" which indicates stubbornness. Hence, the three verbal processes contribute to portraying Egyptian women as cruel and not supportive of their husbands, which implies that Egyptian men are victimized by their wives.

Women are also assigned a number of significant mental processes in the data analyzed. Examples include:

a) 'ommohom hāaysah wā lāysah (Their mother does not know what to do $) \rightarrow$ story (4)

b) ‘̄ârfah al-bīr wā gatāăh (knows everything well) $\rightarrow$ story (44)

c) al-banāt [...] miš fāhmīn al-wasāḩah bitā it haramiyyit al- 'arabiyyāt (The girls [...] cannot

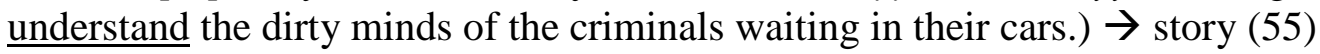


In examples (a) and (c), women are the Sensers of negative mental processes. In example (a), the wife is portrayed as unable to act as well as totally dependent on her husband for financial support. Example (c), too, assigns girls a negative mental process which indicates innocence and, at the same time, an inability to understand something which is easy to understand for men (i.e., the dirty minds of criminals who wish to have sex with innocent girls). Both examples portray Egyptian women and girls as naive and lacking mental abilities which men are naturally endowed with, which, accordingly, makes them always dependent on men for both security and financial support. In example (b), the Senser of the mental process is the wife who, despite the fact that she "knows" that her husband does not have enough money, insists on moving to another house. Hence, the mental processes assigned to women in the book contribute to creating a negative image of Egyptian women.

The relational processes assigned to women are also significant. Examples include:

a) dool kollohom 'ithawwilo walā mu'āhzah li dā 'irāt (Excuse my language, they've all become prostitutes.) $\rightarrow$ story (9)

b) dool wabāl 'aleena wā al- 'iyāzo billāh (They are a plague. May God protect us.) $\rightarrow$ story (9)

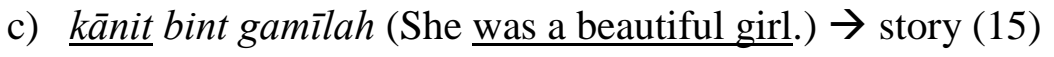

d) al-banāt yā 'eeni lissah fì muntahà al-barā'ah (Poor girls! They are still so innocent.) $\rightarrow$ story (55)

The relational processes assigned to women in the above-mentioned examples are all intensive relational processes in which women are the Carriers. Relational processes are primarily used to assign certain qualities (Attributes) to a participant, and through the Attributes used to describe women in the above-mentioned examples, such processes contribute to creating a highly negative image of them. In examples (a) and (b), the Attribute "plague" is used to describe women (the Carrier of this Attribute) as they have all become "prostitutes" according to the driver. Assigning this process to women contributes to portraying women as the reason behind the moral deterioration of the Egyptian society. In example (c), the Attribute "beautiful" is used by the driver to describe his cousin to whom he proposed, which indicates that women in the Egyptian society are judged, to a great extent, based on their looks. Moreover, a woman's looks is one of the main reasons why a man would propose to a woman. In example (d), the Attribute "so innocent" is used to describe girls as they do not understand the dirty minds of criminals who would like to have sex with them. Such a description draws a contrast between "innocent", and hence naïve and inexperienced, girls as opposed to men who are smart. This presents an image of women as fragile and in constant need of men's protection.

Hence, although there are various process types assigned to women in the book, they all contribute to creating a certain image of women as perceived by men in the Egyptian society. Based on the process types the men in the book assign to women, they seem to view women as fragile beings who are unable to understand much about the world and who are, hence, in constant need for men to protect them. In addition, men seem to view women as completely dependent on them for financial support. Moreover, women seem to be represented most of the time as cruel as they do not stop quarreling with their husbands and creating troubles. In fact, the process types that men assign to women in the book contribute to enforcing a negative image of them. 


\subsection{Discoursal Analysis}

\subsubsection{Character Description and Fragmentation}

Mills (1995, p. 123) argues that "[c]haracters are made of words" and that the reader learns to construct words into a set of ideological messages drawing on his/her knowledge of the way texts are written as well as common social views of men and women. In addition, readers acquire a set of skills that help them interpret the ideological knowledge which texts provide about women and men, particularly at the level of stereotypes. This is because many texts draw on stereotypical knowledge in their portrayal of men and women (Mills, 1995, p. 124). There are different ways of presenting stereotypical knowledge about males and females in a text.

Mills (1995, p. 129) argues that sexism is embedded in presenting females in a text according to stereotypes. In story (35), the driver criticizes the state radio which works for the ultimate purpose of deceiving the people through reporting (or hiding) political events. In describing how the state radio works, he says, "wā ba'deen tițla' 'aleenā muzì it 'atfāl wā tikallimnā bì al-soot bitā " ishrabo al-laban 'abl mā tināmo" (And then a female presenter of children's programmes speaks to us on the radio in her drink-milk-before-you-go-to-bed voice"). The driver intentionally uses the feminine form $m u z i$ ' $a h$ (a female presenter) and not the masculine form $m u z \bar{l}^{`}$ (a male presenter). His comment reflects a stereotype of women as the ones fit for presenting children's programmes as if this were exclusively a feminine job, which contributes to enforcing stereotypes about women in the language.

Fragmentation is another technique which is used as tool of sexism in language. Females are usually described in terms of their legs and other body parts unlike males who are usually described in texts in terms of their heads and their overall size (Mills, 1995, p. 123). In other words, descriptions of women present a "fragmentation" of their bodies. In story (11), the driver uses the following expressions to describe the woman who decided to change her clothes in his taxi:

a) la 'ithā lābsah biloozah miḥazza'ah kidah wā šaklahā hịlw (I found her wearing a beautiful tight blouse.)

b) badit tiḥott 'aḥmar šafāyif wā aḥmar 'alà hudūudhā (She started putting on lipstick and rouge on her cheeks.)

c) rāhit mitalla 'ah al-forša bitā 'it al-rumūšs wā badit ti 'mil fì rumūšh $\bar{a}$ (She took out an eyelashes brush and started working on her eyelashes.)

In these examples, the driver, in his reporting of the incident, does not simply mention that the woman took off her clothes in his car. On the contrary, he provides a detailed description of her "tight blouse", "cheeks" and "eyelashes". This "fragmentation" of the body makes the body "depersonalized, objectified and reduced to its parts" (Mills, 1995, p. 133). Moreover, while narrating the incident, the driver comments on his reaction when he found her taking off her clothes, saying, "'olt hilw hantifarrag bibalāšs" (I said "Nice. Let's have a free view"). Such a comment reflects how he defines her as a woman in terms of her sexual attractiveness and sexual availability as if women exist to satisfy men's desires. This is because fragmentation of the female body is "associated with male focalization", for it represents the female "as an object, a collection of objects, for the male gaze" (Mills, 1995, p. 133). 


\subsubsection{Schemata}

According to the schema theory proposed by Brown and Yule (1983, p. 233), "general knowledge about the world underpins our interpretation not only of discourse, but of virtually every aspect of our experience". They argue that world knowledge is organized in the human memory in several forms, one of which is schemata (Brown and Yule, 1983, pp. 237-238). Schemata can be defined as "the organized background knowledge which leads us to expect or predict aspects in our interpretation of discourse" (Brown and Yule, 1983, p. 248). Mills (1995, p. 152) argues that sexism works at the level of schemata, which, according to Brown and Yule (1983, p. 250), "provide a way of accounting for discourse production and interpretation". Although schemata might differ from one individual to another, they generally tend to be shared and understood in the same way by individuals who belong to a certain culture (Black, 2006, p. 36). In terms of sexism, this is true of the narratives which involve certain ways of thinking about women (Mills, 1995, p. 152). The narratives of some of the taxi drivers in the data analyzed conform to generally known negative schemata about women in the Egyptian society. In most of these narratives, women are presented as wives. Those wives are described in terms of several negative qualities which are part of the schemata shared in the Egyptian society about Egyptian wives. For example, in many narratives, they are presented as wives who are always quarreling with their husbands and turning their lives into hell. Examples include:

a) mirātī dabbit ma 'áyah hină'ah lil samah (My wife quarreled with me and the quarrel turned into a big fight.) $\rightarrow$ story (16)

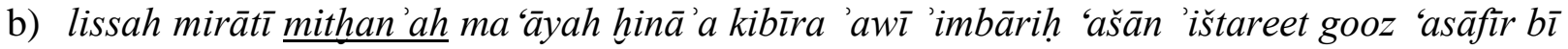
miteen wä hamsin ginee (My wife quarreled with me yesterday, and the quarrel turned into a big fight, because I had bought two sparrows for 250 LE.) $\rightarrow$ story (58)

Women are also represented as wives who are completely dependent on their husbands for protection and financial support and who would not be able to survive without their husbands. In terms of schemata, men in Egypt are considered as the breadwinners of the family and women as financially dependent on their husbands. Examples include:

a) 'ana kān hāyin 'alayya aṭba' fì zummārit ra'abtoh lākin fakkart fì 'iyyālì wā fì al-wiliyya mirātī (I wished I could kill him, but I thought of my kids and my wife.) $\rightarrow$ story (2)

b) al-hukūma zara'it fina al-ro'b min al-gu' 'hallit koll zoogah timsik fì 'ìd gozha wā ti'olloh 'iw'à tinzil, al- 'iyāl hatmūt (The government instilled in us the fear of hunger. It made every wife hold her husband's hand and beg him saying, "Please do not go out; the kids will die.") $\rightarrow$ story (3)

In addition to being represented as wives, women are represented as sexual objects which exist primarily to satisfy men's desires, which conforms to the schemata of how women are thought of in the Egyptian society. Examples include:

a) 'olt ḥilw hantifarrag bibalāšs (I said "Nice. Let's have a free view [of the woman taking off her clothes in the taxi].") $\rightarrow$ story (11)

b) la 'ithā lābsah biloozah miḥazza'ah kidah wā šaklahā ḥilw (I found her wearing a beautiful tight blouse.) $\rightarrow$ story (11) 
Women are also represented in the conversations recorded in the book as weak beings who are, unlike men, unable to endure the hardships of life, which conforms to the schemata shared in Egypt about women as weak. This appears in the following example:

- ' ommoh mastaḥmilitš gālhā al-'alb (His mother could not bear it. She got afflicted with a heart trouble [due to the sickness of her son].) $\rightarrow$ story (18)

In short, the short narratives related by the drivers in the book assign to women qualities which coincide with schemata about women in the Egyptian culture, and such schemata constitute stereotypes of Egyptian women. Each narrative counts as an experience which is "understood by comparison with a stereotypical version of a similar experience held in memory", which is the basic claim of the schema theory (Cook, 1990, p. 1). Generally known schemata about Egyptian women stereotype them as trouble-making wives, completely dependent wives, sexual objects, or weak beings who are unable to endure the hardships of life. Such schemata, functioning through narratives, enforce a negative image of women, which contributes to perpetuating sexism against them.

\section{Conclusion}

In several communities, language works as a powerful tool of maintaining sexism through perpetuating sexist beliefs and representing women as inferior to men. Using Mills' (1995) model of analyzing sexism in language, the analysis of Khaled Al-Khamissi's Taxi, which includes authentic dialogues in Egyptian Colloquial Arabic, shows how sexism in embedded in ECA as used by Egyptian speakers. This sexism shows in ECA expressions on the lexical level (e.g., naming and the semantic derogation of women), the syntactic level (e.g., presupposition and inference, jokes and transitivity choices) and the discoursal level (character description and fragmentation and schemata).

The sexist use of ECA enforces a negative image of women in the Egyptian society. It stereotypes them as weak, vicious, troublesome and dependent, in addition to being sexual objects, which perpetuates sexism against them. The first step on the road of empowering women in the different fields of life is changing the way they are viewed. This should start with changing how they are represented in language by the language users as language is the tool which enforces such images of women. 


\section{References}

Primary Sources:

Al-Khamissi, K. (2009). Taksī: Hawadīt al-mašawīr (14 ${ }^{\text {th }}$ ed.). Al-Shorouk: Cairo.

Secondary Sources:

Academy of the Arabic Language in Cairo. (2005). qaḥbah. In Al-Mu '̌gam Al-Wăğzz (p. 490).

Al-Khamissi, K. (2008). Taxi (J. Wright, Trans). Wiltshire: Aflame Books. (Original work published 2006).

Attardo, S. (2001). Humorous texts: A semantic and pragmatic analysis. New York \& Berlin: Mouton de Gruyter.

Black, E. (2006). Pragmatic Stylistics. Edinburg: Edinburg University Press.

Brown, G., \& Yule, G. (1983). Discourse analysis. Cambridge: Cambridge University Press.

Bucholtz, M. (2014). The feminist foundation of language, gender, and sexuality research. In S. Ehrlich, M. Meyerhoff, and J. Holmes (Eds.), The handbook of language, gender and sexuality (2 ${ }^{\text {nd }}$ ed., pp. 23-47). New York: John Wiley \& Sons Inc.

Cameron, D. (1992). Feminism and linguistic theory (2 ${ }^{\text {nd }}$ ed.). London: Macmillan.

Cameron, D. (1998). The feminist critique of language: A reader (D. Cameron, Ed.). New York: Routledge.

Cameron, D. (2006). On language and sexual politics. London: Routledge.

Cook, G. (1990). A theory of discourse deviation: The application of schema theory to the analysis of literary discourse. PhD Dissertation. Retrieved from https://core.ac.uk/download/pdf/42606046.pdf

Fairclough, N. (1989). Language and power. New York: Longman.

Farwaneh, S. (2005). Asymmetries of male/female representation in Arabic. In A. Jule (Ed.), Gender and the language of religion (pp. 41-62). New York: Palgrave Macmillan.

Halliday, M. A. K. (1994). An introduction to functional grammar (2 ${ }^{\text {nd }}$ ed.). London: Edward Arnold.

Haratyan, F. (2011). Halliday's SFL and social meaning. $2^{\text {nd }}$ International Conference on Humanities, Historical and Social Sciences, IPEDR, 17, 260-264. Retrieved from http://www.ipedr.com/vol17/49-CHHSS\%202011-H10074.pdf

Hegarty, P., Korchmaros, J., \& Pratto, F. (2007). When race and gender go without saying.

Social Cognition, 25, 221-247. Retrieved from

https://www.academia.edu/1003087/When_race_and_gender_go_without_saying

Hughes, G. (2015). An encyclopedia of swearing: The social history of oaths, profanity, foul language, and ethnic slurs in the English-speaking world. New York: M.E. Sharpe. 
Lazar, M. M. (2005). Politicizing gender in discourse: Feminist critical discourse analysis as political perspective and praxis. In M. M. Lazar (Ed.), Feminist critical discourse analysis: Gender, power and ideology in discourse (pp. 1-28). New York: Palgrave Macmillan.

Lazar, M. M. (2017). Feminist Critical Discourse Analysis. In J. Flowerdew and J. E. Richardson (Eds.), The Routledge handbook of critical discourse analysis (pp. 272-387). New York: Routledge.

Litosseliti, L. (2006). Gender and language: theory and practice. London: Hodder Education.

Litosseliti, L., \& Sunderland, J. (2002). Gender identity and discourse analysis: Theoretical and empirical considerations. In L. Litosseliti \& J. Sunderland (Eds.), Gender identity and discourse analysis (pp. 3-39). Amsterdam: John Benjamins.

Menegatti, M., \& Rubini, M. (2017). Gender bias and sexism in language. Oxford research encyclopedia of communication. Retrieved from http://oxfordre.com/communication/view/10.1093/acrefore/9780190228613.001.0001/acr efore-9780190228613-e-470?print=pdf

Mills, S. (1995). Feminist stylistics. London: Routledge.

Mills, S. (1997). Discourse. London: Routledge.

Mills, S. (1998). Post-feminist text analysis. Language and literature, 7 (3), 235-253. Retrieved from https://journals.sagepub.com/doi/10.1177/096394709800700304

Mills, S. (2002). Third wave feminist linguistics and the analysis of sexism. Retrieved from https://extra.shu.ac.uk/daol/articles/open/2003/001/mills2003001.html

Mills, S. (2003). Caught between sexism, anti-sexism and 'political correctness': Feminist women's negotiations with naming practices. Discourse and Society, 14 (1), 87-110. Retrieved from https://journals.sagepub.com/doi/10.1177/0957926503014001931

Mills, S. (2008). Language and sexism. Cambridge: Cambridge University Press.

Nayef, H. \& El-Nashar, M. (2014). Promoting masculine hegemony through humour: A linguistic analysis of gender stereotyping in Egyptian sexist Internet jokes. International Journal of Linguistics and Communication, 2 (4), 69-84. Retrieved from https://www.researchgate.net/publication/272373850_Promoting_Masculine_Hegemony through_Humour_A_Linguistic_Analysis_of_Gender_Stereotyping_in_Egyptian_Sexist Internet_Jokes

Raskin, V. (1985). Semantic Mechanisms of Humor. Dordrecht: Reidel.

Richardson, J. E. (2007). Analysing newspapers: An approach from critical discourse analysis. New York: Palgrave Macmillan.

Rosenbaum, G. M. (2019). Curses, Insults and taboo words in Egyptian Arabic: In daily speech and in written literature. In G. Grigore \& L. Sitaru (Ed.), Curses and profanities in the languages and cultures of the Middle East and North Africa (pp. 153-188). Bucharest: Center for Arab Studies. 
Short, M. (2013). Exploring the language of poems, plays and prose. New York: Longman.

Simpson, P. (1993). Language, ideology, and point of view. London, New York: Routledge.

Speer, S. (2005). Gender talk: Feminism, discourse and conversation analysis. London: Routledge.

Spender, D. (1980). Man made language. London: Pandora Press.

Stahlberg, D., Braun, F., Irmen, L., \& Sczesny, S. (2007). Representation of the sexes in language. In K. Fiedler (Ed.), Social communication (pp. 163-187). New York: Psychology Press.

Sunderland, J. (2004). Gendered discourses. New York: Palgrave Macmillan.

Swim, J. K., Mallett, R., \& Stangor, C. (2004). Understanding subtle sexism: Detection and use of sexist language. Sex roles, 51, 3/4, 117-128. Retrieved from https://www.researchgate.net/publication/227040305_Understanding_Subtle_Sexism_De tection_and_Use_of_Sexist_Language

Van Dijk, T. A. (2001). Critical discourse analysis. In D. Schiffrin, D. Tanner \& H. Hamilton (Eds.), The handbook of discourse analysis (pp. 352-371). Oxford: Blackwell.

Wales, K. (2011). A dictionary of stylistics ( $3^{\text {rd }}$ ed.). New York: Routledge.

Weatherall, A. (2002). Gender, language and discourse. London: Routledge.

Wodak, R. (1997). Introduction: Some important issues in the research of gender and discourse. In R. Wodak (Ed.), Gender and discourse (pp. 1-20). London: Sage. 